\title{
Sabahattin Ali Romanlarındaki İktisat Teorisi İzleri
}

\author{
Eda ERĞUN ${ }^{1}$ ve Umut HALAÇ ${ }^{2}$ \\ $\ddot{O} z$
}

Belirli bir dönemi incelerken o döneme ait kapsamlı ve analitik bilgiye ulaşmak için ekonomik, kültürel, psikolojik ve sosyolojik değişkenlerin göz ardı edilmemesi gerekliliği disiplinler arası çalışmaların önemini bir kat daha artırmaktadır. Bu perspektif doğrultusunda, edebiyat ve iktisat bilimi disiplinler arası bir çalışma alanı olarak karşımıza çıkmaktadır. Zira, bir edebî eser üretildiği dönemin ekonomik, kültürel, sosyolojik ve psikolojik izlerini yansıtma konusunda ayna işlevini üstlenebilir ve çoklu okumalara imkân tanıyan bir özelliğe haizdir. Bu çalışmanın amacı, iktisat ve edebiyat ilişkisi bağlamında Kuyucaklı Yusuf ve Kürk Mantolu Madonna romanlarını analiz etmektir. Araştırmada öncelikle Sabahattin Ali kısaca tanıtılmış, ardından iki romanın kronolojik olarak olay örgüsü aktarılmış ve buradan hareketle romanların ihtiva ettiği iktisadî ögeler tespit edilmiştir. Kuyucaklı Yusuf romanı ile ilişkili olarak döneminin iktisadi teması ile olan bağıntı ortaya koyulmuş, Kürk Mantolu Madonna romanın da ise iki ayrı dönem bağlamında Alman ve Türk ekonomileri incelenmiştir. Yapılan analizler sonucunda iktisat bilimi ve edebiyatın yakın ilişki içinde olduğu yadsınamaz bir gerçek olarak karşımıza çıkmaktadır. Özellikle incelenen eserler bağlamında sermayenin gücü ve bu gücün hukuk üzerindeki yönlendirici etkileri ortaya konulmuştur. Yoksulluk, gelir eşitsizliği ve suç kavramı arasındaki ilişkilerin altı çizilmiş ve bunların toplum yapısı üzerindeki etkileri ortaya konulmaya çalışılmıştır.

Anabtar Kelimeler: İktisat, Edebiyat, Sabahattin Ali, Kuyucaklı Yusuf, Kürk Mantolu Madonna

\section{Traces of Economic Theory in Sabahattin Ali's Novels}

\begin{abstract}
While examining a particular period, the necessity of not ignoring economic, cultural, psychological and sociological variables in order to reach comprehensive and analytical information about that period increases the importance of interdisciplinary studies. In line with this perspective, literature and economics emerge as an interdisciplinary field of study. Because, literature can assume the mirror function in reflecting the economic, cultural, sociological and psychological traces of the period in which it was produced, and has a feature that allows multiple readings. The aim of this study is to analyze the novels Kuyucaklı Yusuf and Kürk Mantolu Madonna in the context of the relationship between economics and literature. In the research, firstly Sabahattin Ali was introduced briefly, then the plot of the two novels was transferred chronologically, and the economic elements contained in the novels were determined. In the novel Kuyucaklı Yusuf, the economic theme of the period was revealed, and in the novel Kürk Mantolu Madonna, German and Turkish economies were examined in the context of two separate periods. Based on the analysis, it was determined that economics and literature are in close relationship. Especially, in the context of the examined novels, the power of capital and its guiding effects on law are presented. The relationship between poverty, income inequality and crime concept has been underlined and their effects on social structure have been tried to be revealed.
\end{abstract}

Key Words: Economics, Literature, Sabahattin Ali, Kuyucaklı Yusuf, Kurk Mantolu Madonna

\section{Atıf İçin / Please Cite As:}

Erğun, E. ve Halaç, U. (2022). Sabahattin Ali romanlarındaki iktisat teorisi izleri. Manas Sosyal Arastırmalar Dergisi, 11(1), 176-187.

Geliş Tarihi / Received Date: 27.04.2021

Kabul Tarihi / Accepted Date: 26.06.2021

\footnotetext{
1 Yüksek Lisans Öğrencisi - Türkiye- İstanbul Üniversitesi Sosyal Bilimler Enstitüsü, İktisat Teorisi Bilim Dalı, edaergun@hotmail.com

D ORCID: 0000-0002-4405-2895

2 Doç. Dr. - Türkiye- Yaşar Üniversitesi İşletme Fakültesi Ekonomi Bölümü, umut.halac@yasar.edu.tr

(D) ORCID: 0000-0001-7540-4219
} 


\section{Giriş}

İktisat, insanlığın varoluşundan beri mevcuttur. Zaman içinde meydana gelen olay ve olgular nedeniyle bireyler ve toplumlar sürekli olarak değişime uğramıştır. İktisat ve toplum, insanın ortak değer olması nedeniyle birbiriyle dinamik bir ilişki içindedir. Toplumlar arasında gözlemlenen ortak istek, ihtiyaç, gelenek ve kültür farklılıkları nedeniyle iktisadi yapılar arasında da farklilıklar gözlemlenebilir (Kazgan, 1991, s. 41). Bu durumda farkl11ıkları oluşturan birçok değişken söz konusu olunca bir toplumun iktisadî bir dönemini incelerken başvurulan veriler, çıktılar ve somut ürünler pek tabii ki daha kapsayıcı bilgilere ulaşılmasını sağlayacaktır. Dolayısıyla, edebiyat, bu kuşatıcı bilgileri elde etmek için yararlanılan bir bilim dalı olarak karşımıza çıkmaktadır.

Edebiyat, gerçekte sosyal sürecin bir yansıması değil, fakat sosyal süreç de dahil olmak üzere bütün o dönem tarihinin özü, esası ve özetidir (Wellek ve Warren, 2011, s. 109). Dolayısıyla, ekonomik etkilerin edebiyat eseri üzerindeki etkisi yadsınamaz yorumu yapılabilir. Örneğin, Dostoyevski'nin Suç ve Ceza romanında Raskolnikov'un bir tefeciyi öldürmesinin ardında yatan en önemli gerekçe Rusya'nın ve Raskolnikov'un içinde bulunduğu ekonomik sıkıntılardır. Buradan yola çıkılarak, ülkelerin içinde bulundukları ekonomik durumun; edebiyat, tiyatro ve dilin şekillenmesinde doğrudan rol oynadığ1 söylenebilir (Watts ve Smith, 1989, s. 291).

Dolayısıyla, Türk Edebiyatı'nın önemli yazarlanından Sabahattin Ali'nin Kuyucaklı Yusuf ve Kürk Mantolu Madonna romanları, iktisat ve edebiyat arasındaki ilişkiyi yansıtmak amacıyla incelenecektir. Araştırmada öncelikle iktisat ve edebiyat ilişkisinin teorik zemini sunulmuş, Sabahattin Ali'nin yazar kimliği tanıtılmıs, ardından iki romanın kronolojik olarak olay örgüsü aktarılmıss, buradan hareketle romanların ihtiva ettiği iktisadî ögeler tespit edilmiştir. Öncelikle, Kuyucaklı Yusuf romanı ve döneminin iktisadi teması arasındaki bağlantı kurulmuş daha sonra Kürk Mantolu Madonna romanının geçtiği iki ayıı dönem, Alman ve Türk ekonomileri açısından incelenmiştir. Buna istinaden iktisat ve edebiyat ilişkisi bağlamında romanlara ilişkin bir analiz yapılmıştır. İkinci bölümde, Kuyucaklı Yusuf ve Kürk Mantolu Madonna romanlarının yazarı Sabahattin Ali'den ve bağlı olduğu edebiyat akımından bahsedilmiş, romanların olay akışı okurun konuya hâkim olabilmesi için kısaca anlatılmıştır. Takip eden bölümlerde, öncelikle, Kuyucaklı Yusuf romanı ve döneminin iktisadi teması arasındaki ilişki ortaya konulmuş daha sonra Kürk Mantolu Madonna romanının geçtiği iki ayrı dönem, Alman ve Türk ekonomileri açısından incelenmiştir. Son bölümde, yapılan incelemeler sonucunda edebiyat ve iktisat arasındaki ilişkinin Sabahattin Ali'nin romanları üzerinden izleri ortaya koyulmaya çalışılmıştır.

\section{İktisat ve Edebiyat}

Bilinen ilk ekonomistler, Batılı düşünce geleneğini başlatan Yunan filozoflardır ve ekonomiyi hane halkı temelinde açılamaya çalışmışlardır (Kishtainy, 2017, s. 18). Newton'un klasik fizik yaklaşımındaki evrende düzenli ve değişmez kanunlar olduğu görüşü ortaya çıktıktan sonra benzer olarak toplumlar da içsel kanunlara göre işleyen düzenli sistemler olarak planlanmıştır (Kazgan, 1991, s. 57). Bu görüş doğrultusunda toplumların iktisadi temalarının belirlenmesi için toplumun düşünce, gelenek ve isteklerinin göz önünde tutulması gerekmektedir. Bir toplumun istekleri, ihtiyaçları nelerdir, sorusuna yanıt ararken o toplumun ürettiği edebiyat ürününde, bazı cevapların yer alabileceği göz ardı edilemez. Söz gelişi, Adam Smith’i de kapsayan değerlendirmeler olmaksızın bir 18.yy. İngiliz edebiyatı tarihi düşünmek zor ise aynı şekilde iktisat tarihi yazarken de edebiyat ve diğer disiplinlerinle olan ilişki de önem arz etmektedir (Wellek ve Warren, 2011, s. 24).

İktisat bilimi, sıkça kullanılan tanımıyla, kıt kaynakların insanların sınırsız ihtiyaçlarını karşılamak amaciyla düzenlenmesidir şeklinde tanımlanmaktadır ve buna benzer temalar zaten edebiyatta bulunmaktadır (Watts ve Smith, 1989, s. 291). Edebiyat, insan davranışlarını ve onları bu davranışlara iten motivasyonları iktisatçıların yapabildiğinden daha güçlü bir şekilde aktarabilmektedir. Edebî tanımlar, belirli bir yer ve zamandaki ekonomik durum ve kurumların ya da bireysel davranışların kanıtıdır (Watts, 2002, s. 377). İçinde bulundukları ekonomik durum hakkında insanların düşünceleri incelenmek istendiğinde, toplumsal durumu okuyucuya başarıyla aktarmış edebiyatçıların eserlerinin kullanması faydalı bir yöntem olarak karşımıza çıkmaktadır (Özdemir, 2011, s. 106). Bu görüşler 1şı̆̆ında bu çalışmanın amacı seçilmiş edebiyat eserlerini kullanarak dönemin iktisadi yapısını incelemektir. 


\section{Sabahattin Ali ve Romanların Olay Örgüsü}

Cumhuriyet Dönemi Türk Edebiyatı'nın önemli yazarlarından biri olan Sabahattin Ali, 25 Şubat 1907'de (Rumi 12 Şubat 1322) Gümülcine Sancak'ına (Bulgaristan) bağlı Eğridere (şimdiki adı Ardino) ilçesinde dünyaya gelmiştir. Babası asker olan Sabahattin Ali ilkokul eğitimi süresince Çanakkale'de yaşamış ve Birinci Dünya Savaşı'nın en sıcak çatısmalarının olduğu bir bölgede büyümek zorunda kalmıştır. Karakteri, savaş nedeniyle oluşan olumsuzluklar gibi dış etkenler ve aile içindeki huzursuzluklar gibi iç etkenler tarafindan şekillenmiştir. Savaşın korkunçluğundan sığınacak bir yer arayan küçük çocuk, kendisini teselli edecek yer olarak ailesine yönelmiş fakat babası ile annesi arasındaki yaş ve zevk dengesizliğinden dolayı ailesinden de umduğu desteği bulamamıştır (Korkmaz, 1991, s. 6).

Savaş sonrası gecikmeli olsa da ilkokul eğitimini tamamlar ve daha sonra öğretmen okuluna başlar. Balıkesir öğretmen okulunda bir süre okuduktan sonra İstanbul öğretmen okuluna geçer. Huzursuz aile ortamından uzaklaşmak ona hayatını yeniden düzenleme şansı verir. Şiir ve hikâye denemelerine de ilk olarak bu zamanlarda başlar. Sabahattin Ali'nin öğretmen okulunda geçirdiği 5 yıl onun için oldukça faydalı olmuş günlük tutmaya, sinema ve tiyatroya gitmeye ve okumaya daha fazla zaman ayırmaya başlamıştır. Daha sonra elde edilen günlüğü incelendiğinde yazarın, gençliğinde yalnız, içine kapanık ve karamsar bir ruh yapısına sahip olduğu söylenebilir (Korkmaz, 1991, s. 9-14).

Ailesindeki bitmeyen problemlerin yanı sıra öğretmen okulunun son zamanlarına doğru babasının ölümü yazarı derinden sarsmıştır. Öğretmen okulunu bitirdikten sonra dayısının bulunduğu Yozgat Cumhuriyet okuluna tayini gerçekleşir. Burada hekim olan dayısının sosyal çevresi tarafindan hemen kabul görür ve sevilir. Fakat yazarın mizacı bu tür sosyal çevreye dahil olmasını engellemekte ve kendi iç yalnızlığı kalabalıklar arasında bile devam etmektedir. Sabahattin Ali'nin Yozgat'ta geçirdiği bir yll ona derin bir yalnızlı̆̆ yaşatmıştır. Dayısının Ankara'da başka bir hastaneye geçmesiyle birlikte o da Ankara'ya taşınır. Ankara'da dayısının Millî Eğitim Bakanlığındaki tanıdıkları aracılığıyla dil öğrenmek için yurtdışına öğretmen gönderme sınavina girer ve sınavda başarılı olur. Böylece Kasım 1928'de Almanya macerası başlamı̧ olur.

Sabahattin Ali, Almanca vasıtasıyla ulaştı̆̆1 yeni dünyada Turgenyev, Gorki, Poe, de Maupassant, von Kleist, Hamsun, Hoffmann ve Mann gibi yazarları tanır. Onların eserlerinden etkilenir ve ilham alır. $\mathrm{Bu}$ etkileri daha sonra yazacağı romanlarda görmek mümkündür. Eğitiminin daha uzun sürmesi beklenirken 2 yll sonra Türkiye'ye geri döner (geri gönderilir). Geri dönüşü konusunda farklı görüşler olmakla birlikte akla en yatkın olanı fevri bir kişiliğe sahip olan yazarın dönemin Alman milliyetçiliğine kurban gitmesidir (Korkmaz, 1991, s. 19). Türkiye'ye döndükten sonra Almanca öğretmenliği yapmak için Aydın'da göreve başlar fakat burada komünizm propagandası yaptığı iddiası ile hakkında soruşturma açıllır ve soruşturma devam ederken bir süre hapiste yatmak zorunda kalır. Bu hapislik sürecinde Kuyucaklı Yusuf ve Candarma Bekir gibi hikayeleri için malzemeler toplar. Hakkındaki soruşturmadan aklanınca Konya'ya Almanca öğretmenliğine atanır. Burada da dışarıdan bakıldığın zaman çok hareketli ve heyecanlı bir hayat sürerken içinde derin bir yalnızlı̆ı yaşamaktadır. Fakat Konya'da kendisi hakkında dava açılır ve bu davada 14 ay ceza alıp, hapishaneye girer. Böylece devlet memurluğu da elinden gitmiş olur. Konya cezaevinden sonra Sinop cezaevine gönderilir. İki ceza evinde de oldukça sıkıntılı ve telaşlı bir ruh halinde içinde olduğu gözlemlenir. 10 ay hapiste kaldıktan sonra çıkan afla birlikte serbest kalır fakat hapishanede geçirdiği süre boyunca oradaki insanları incelemiş ve hapishaneyi bir laboratuvar gibi kullanmıştır (Korkmaz, 1991, s. 23).

Serbest kaldıktan sonra öğretmenliğe geri dönmek için başvurur fakat bu konuda kararın alınması zaman alacaktır. Bu süre zarfında arkadaşlarının yanında kalır ve maddi bakımdan herhangi bir problemi olmadığı görülmektedir. Tercümanlık ve gazetecilik de yapabilmesine rağmen memuriyete geri dönmek için yoğun çaba içindedir. Uzun uğraşlar sonrası öğretmenliğe dönmesine izin verilmez fakat talim ve terbiye kuruluna ikinci sınıf memur olarak atanır. Bu dönemde yaşadığı sıkıntılar onun iyice içine kapanmasına sebep olmuştur. Hızlı gerçekleşen evliliği ve memuriyetteki yükselmesi daha iyi koşullarda yaşamasına ortam hazırlamakla beraber daha sakin bir yaşam sürmesini de beraberinde getirmiştir. 2 . Dünya savaşının patlak vermesiyle beraber 10 ay sürecek olan yedek subaylık görevi için askere alınır. Mecburi görevinin bitmesinden sonra göreceli olarak daha sakin bir zaman geçirir. 1943'e kadar birçok yazardan çeviriler yapmış ve birçok eser ortaya koymuştur (Korkmaz, 1991, s. 26-30).

1944 yllinda itibaren "bencil ve gösteriş düşkünü” yaşam şekli yüzünden Marksist teoriyi savunanlar tarafindan şiddetle eleştirilmiş ve politik kavgaların içine çekilmeye başlanmışır. Burjuva meraklısı zevkleri olmakla suçlanan Sabahattin Ali sadece Marksistler tarafından eleştirilmekle kalmamıs, Millî Eğitim 
Bakanlığındaki hızlı yükselişinin liyakate uygun olmadığı ve bazı eserlerinde Türk büyüklerine hakaret ettiği gerekçesiyle milliyetçiler tarafından da şiddetle eleştirilmiştir. Daha sonrasında Nihal Atsız ile yaşadıkları dava süreci gelecekte yaşayacağı zor sürecin de başlangıcı olarak görülmektedir (Korkmaz, 1991, s. 33-36). Komünistlerin eleştirileri giderek artıyordu. Hatta arkadaşları onun artık güvenilir olmaktan çıktı̆̆ını, gizli saklı yaptıkları toplantılardan sonra milliyetçi "faşist" arkadaşlarını ziyarete gittiği tespit ettiklerini söylemekteydiler. Davalar birbirini takip eder, 1947 yllının sonuna kadar birçok defalar hapse girip çıar. 1947 sonunda hapishaneden çıktı̆ı̆nda bütün bu kavgalardan yorulmuş ve büyük bir borç batağına saplanmış bir durumdadır. Elinde avucunda para eden ne varsa satarak borçlarını kapatmaya çalışır. Yazar olarak hiçbir şey yapamadığı için arkadaşlarının yardımıyla alınan kamyonla nakliyecilik yapmaya başlar. Aslında nakliyecilik işi Sabahattin Ali'nin bir uğraşı sahibi olması için arkadaşları tarafindan finanse edilen bir iştir yani bu işten herhangi bir kazanç sağlayamamaktadır. Bu süreçte pasaport almak için başvurmuş ve başvurusu reddedilmiştir. Başvurusu reddedilince ülkeden kaçak olarak çıkmayı planlar ve bunun için de hapisteyken tanıştığı bir arkadaşından yardım ister. Arkadaşı, kendi şebeke elemanlarından silah kaçırmak suçundan ordudan atılmış olan Ali Ertekin'i Sabahattin Ali'ye kaçı̧şta rehberlik etmesi için görevlendirir. Bulgaristan üzerinden Avrupa'ya geçme planı yapılmış ve 31 Mart 1948 günü İstanbul'dan yola çıkılır. Sınıra yakın bir yerde sınırı geçmek için en uygun zamanın gelmesi beklenmeye başlanır. Bekleme sırasında neler olduğu bilinmemekle birlikte Ali Ertekin'in 28 Aralık 1948'de verdiği ifadeye göre Sabahattin Ali'nin Bulgaristan üzerinden Rusya'ya geçerek Türkiye'de komünist ihtilalini başlatacağını iddia eden Ali Ertekin tarafindan öldürüldüğ̈ görülmektedir. Böylece Sabahattin Ali'nin ölümü üzerine birkaç y1l daha sürecek olan tartışmalar başlamış olur. Bir kesim aslında cesedin başkasına ait olduğu ve Sabahattin Ali’nin Avrupa'da veya Rusya'da yaşadığını iddia ederken başka bir kesim de Sabahattin Ali'nin devlet tarafindan öldürüldügünü iddia etmektedirler. Bütün bu görüşler ve iddialara rağmen Sabahattin Ali’nin ölümü üzerindeki sis perdesi kaldırllamamıştır (Korkmaz, 1991, s. 45)

Sabahattin Ali, gerçekçilikten etkilenen bir yazar olarak romanlarında karakterlerinin başına gelen olayları anlatırken, anlattığı dönemin toplumsal sorunlarına sşık tutmuş ve sosyal meselelerden beslenerek topluma yol göstermeyi hedeflemiştir. Bu sayede okuyucu, yazarın eserlerinde yer alan karakterlerin söylem ve eylemlerinin arka planını da kavrayarak zamanın ruhuna uygun değerlendirme şansı yakalamıştır. Sabahattin Ali, toplumsal yapıyı inşa eden sisteme yönelik eleştirilerini açık bir şekilde ortaya koyarak daha aktif bir eleştirel yöntemin gelişmesine katkı sağlamıştır. Onun eserlerinde, zamanın siyasi ortamı göz önüne alındığında ekonomik ve siyasi koşullar altında ezilen insanların hikayelerini gerçekçi bir şekilde anlatmayı tercih etmesi aslında oldukça cesur bir davranıştır. Sabahattin Ali'nin eserlerinde aydını, köylüsü, bürokratı, yeni türeyen burjuvası ve kapitalist eşrafıyla bir dönemin Türkiye'si vardır ve bu karakterler sınıfsal özellikleriyle ön plana çıkartılmıştır (Şenderin, 1996, s. 38-39).

Bu çalışmada incelenen ilk roman olan Kuyucaklı Yusuf romanı adını aldığı Kuyucak köyünde Yusufun anne ve babasının eşkıyalar tarafindan öldürülmesiyle başlar. Olay yerini incelemeye giden Kaymakam Salahattin Bey, bu küçük çocuğun yaşadığı travmaya rağmen sergilediği olgun davranışlardan etkilenir ve onu yanına alarak kendi kızı Muazzez ile birlikte büyütür. Yusuf, büyüdüğünde Muazzez’e âşık olur fakat onunla kardeş gibi büyütüldügü için gerek Salahattin Bey'e ihanet etmiş olma düşüncesi gerekse en yakın arkadaşı Ali’nin de Muazzez'e âşık olması nedeniyle Muazzez'e olan aşkını bir türlü dile getiremez. Annesi ise güzel bir kız olan Muazzez'i kasabanın zenginlerinden Hilmi Bey’in ailesine gelin vermek istemektedir. Fakat Hilmi Bey'in oğlu Şakir kasabada kötü bir itibara sahiptir. Yusuf bir bayram günü Şakir'in Muazzez'e asıldığını görünce sinirine hâkim olamaz ve Şakir'e yumruk atar, Şakir'in kin ve nefreti bu olay ile derinleşir. Evliliğin engellenmesine Yusufun yumruk atması sebep olur. Yusufun sözüne hak veren Salahattin Bey, Hilmi Bey ve ailesinin düşmanlığını kazanır. Bir zaman sonra Salahattin Bey bir kumar oyununda Hilmi Bey’e karşı borca düşürüldüğünde Salahattin Bey’in evliliğe itirazı ortadan kalkar. Yusuf, arkadaşı Ali'den aldığı para ile borcu kapatır. Ali'nin tek isteği ise Muazzez'le evlenmektir. Yusuf daha önce bahsedilen nedenlerden ötürü kendisi ile Muazzez'in asla beraber olamayacağını düşündügünden romanda iyi bir insan olarak betimlenen Ali'yle evlenmesine karşı çıkmaz. Artık tüm kasaba Ali ile Muazzez'in evleneceği haberini duyar. Bunu duyan Şakir bir başkasının düğününde herkesin gözü önünde Ali'yi tabancayla vurarak öldürür. Tüm kasaba buna şahit olur. Fakat Şakir'in ceza almas1 türlü oyunlarla önlenerek tüm suçlardan beraat etmesi sağlanır. Yusuf, tüm bu olanlar karşısında Muazzez'e karşı olan hislerini artık gizleyemez duruma gelmiştir. Muazzez'i kaçırır. Bu kaçırma Muazzez'in annesi tarafindan tepkiyle karşılanmış olsa da Salahattin Bey bu evliliğe onay vererek onları kasabaya geri getirir. Evlilik öncesi düzenli bir işi olmayan Yusuf, devlet dairesinde işe başlar. Salahattin Bey'in beklenmeyen ölümüyle evi geçindirme sorumluluğu tamamen Yusufa kalır. Salahattin Bey'in yerine gelen 
kaymakam İzzet Bey, Yusufa sürekli kasaba dışına çıkmasını gerektirecek işler vermektedir. Bu durumdan yararlanan Muazzez'in annesi ise kızını alıp yeniden Hilmi Bey'in evindeki alemlere götürmeye başlar. Bu alemlerde yalnızca Hilmi Bey ve ailesi değil, kaymakam İzzet Bey'den jandarma komutanına kadar kasabanın önde gelenleri de bulunmaktadır. Muazzez'deki tuhaflıkları fark eden Yusuf, bir göreve gönderilmesine rağmen yarı yoldan eve döner fakat evde kimseyi bulamaz. Hilmi Beylerdeki aleme gittiklerini öğrendiğinde oraya doğru yola koyulur. Kapıyı açıp içeri girdiğinde, aslında bir süredir aklına gelen düşüncelerin doğru olduğunu fark eder. İçki sofrasının çevresinde Kaymakam İzzet Bey, Hilmi Bey, Şakir ve daha nice insanlar oturmuş ve karısı Muazzez sarhoş bir şekilde divana uzanmış kendisini öpmeye çalışan jandarma komutanından kendisini korumaya çabalıyordur. Yusuf öfkesine hâkim olamayarak önce kamçı ile saldırır. Kamçı lambaya çarparak odayı aydınlatan ışığa vurur. Işık sönerken Yusuf, Şakir'in silahını çektiğini fark eder ve kendisi de silahını çekerek ateş etmeye başlar. Odada nereden bir ses duysa oraya doğru ateş eder. Sonunda karısına seslenir ve karanlıkta karısını kucağına alır, orayı terk eder. Yolda Yusufun vurduğu insanlardan birinin Muazzez olduğu anlaşıldığında ise artık çok geçtir.

Kuyucaklı Yusuf romanı Osmanlı Devleti'nin son dönemlerinde geçmektedir ve her ne kadar Kuyucak'taki bir cinayetle başlasa da kasabayı ve kasaba sosyolojisinin içine giren köylü tipini anlatmaktadır. Olay örgüsünde, eşkıyalar tarafından saldırıya uğramış bir çocuk ve aile, sermaye bakımından güçlü biri tarafindan zarar görmüş bürokratlar ve esnaf (Bakkal Ali) vs. gibi yoksulluk odaklı problemler zinciri vardır. Buna benzer olarak, çalışmada incelenen diğer bir roman olan ve genellikle aşk romanı olarak algılanan Kürk Mantolu Madonna romanı da dünya tarihindeki iki önemli savaş döneminin iktisadi etkilerini barındıran bir eser olarak karşımıza çıkmaktadır.

Roman, İkinci Dünya Savaşı öncesi ve Birinci Dünya Savaşı sonrası olmak üzere iki ayrı zaman aralığını kapsamaktadır. Romanın anlatıcısı ve Raif Efendi ile sonradan iş arkadaşı olan genç, uzun süren bir iş arama süreci sonrasında yeni başladığı işinde oda arkadaşı Raif Efendi'yle tanışır. Raif Efendi’nin iş yerindeki yalnızlığ1 ve sessizliği onun ilgisini çeker. Son görüşmelerinde Raif Efendi, arkadaşından iş yerindeki kişisel eşyalarını getirmesini rica eder. İstediği kişisel eşyaların içinde bir defter de mevcuttur. Arkadaşı defteri getirdiğinde, Raif Efendi öleceğini düşündüğü için ondan içinde anılarının bulunduğu defteri odada bulunan sobada yakmasını rica eder. Arkadaşı ise henüz tam olarak tanıyamadığı Raif Efendi'yi biraz olsun anlayabilmek için defteri okuma arzusu duyar ve ondan izin alır. Böylelikle romanın zamanı Birinci Dünya Savaşı dönemine geri döner ve genç Raif in hayatı okuyucuya anlatılır. Genç Raif, babası tarafindan sabun imal etmeyi öğrenmesi için Almanya'ya gönderilir. Almanya'da bir resim sergisinde "Kürk Mantolu Madonna" isimli resimle karşılaşır. Resmin güzelliği karşısında adeta büyülenen genç adam, resmi her gün saatlerce izleyecek kadar etkilenmiş olsa da asıl hayatını değiştiren olay resimdeki kadın Maria Puder'le tanışmasıyla gerçekleşir. Raif ona ilk andan beri hayranlık dolu bir aşk besler. Fakat Maria'nın tecrübelerinden kaynaklanan insanlara karşı bir güvensizliği vardır. Bu nedenle başta Raifin aşkına karşılık vermez ama ona arkadaş olmayı teklif eder. Raif onun yanında olabilmek için bu teklifi kabul eder. Zaman geçtikçe Maria, Raifi tanımakta ve ona karş1, Raif in kendisine duyduğu aşka benzer duygular beslemeye başlar. Sonunda birbirlerine aşklarını itiraf ederler fakat Maria bir hastalığa yakalanır. Raif, her geçen an onun yanındadır ve aşkları onları daha da yakınlaştırmaktadır. Bu süreç içinde Raif, Türkiye'de bulunan ailesinden bir mektup alır. Mektuba göre Raifin babası ölmüştür. Ailesi artık ona para gönderemeyecek durumdadır bu nedenle Raifi geri çağırırlar. Raif ve Maria, birbirlerine tekrar bir araya geleceklerine dair sözler vererek ayrllmak zorunda kalırlar. Raif in tek isteği Türkiye'deki işleri yoluna koyarak Maria'yı yanına almaktır. Lakin bu hiç gerçekleşmez. Yıllar sonra, Raif Efendi'nin son rahatsızlığından birkaç gün önce, Raif Ankara'daki tren garındadır. Orada Almanya'da kaldığı pansiyondan komşusuyla Bayan Tiedemann ile karşılaşır. Kadının yanında küçük bir kız çocuğu da vardır. Raif Efendi, ondan Maria'yı Almanya'da bıraktı̆̆ı sırada hamile olduğunu ve sevdiği kadının hastalık sonucunda öldüğünü öğrenir. Orada yanlarında duran kız çocuğu Raif ile Maria’nın kızıdır. Raif, onların Almanya'ya dönmesine engel olmak bir yana çocuğun babasının kendisi olduğunu bile söyleyemez. Yaşadığı şaşkınlık, acı ve karamsar duygularla saatler boyunca, yağan kara aldırış etmeden yürür. Rahatsızlığı işte bu nedenle şiddetlenir. Arkadaşı, defteri kapattığında Raif Efendi hakkında öğrendiklerinin hissettirdiği karmaşı duygularla onun evine koşar fakat geç kalmıştır. Raif Efendi ölmüştür. Kürk Mantolu Madonna romanı, yoksulluğun yanı sıra sınıf ayrımı, işsizlik ve enflasyon kavramlarılla iki farklı dönemdeki Türk ve Alman ekonomisine dair izleri de yansitır.

\section{Kuyucaklı Yusuf ve İktisat İlişkisi}

Kuyucaklı Yusuf romanı, Osmanlı Devleti'nin son yıllarında gerçekleşen olayları konu almaktadır. Önceki bölümlerde bahsedilen edebiyat ve ekonomi ilişkisinin kurulması için öncelikle Osmanlı'nın son 
dönemine ait ekonomik durumdan bahsetmek yerinde olacaktır. Fetihlerin durmasindan sonraki dönemdeki Osmanlı Devleti, ekonomik sistem olarak gelişimini tamamlayamamış bir tarım ülkesi olarak karşımıza çıkmaktadır (Kongar, 2013, s. 339). Sanayileşme, etkili ve birbirini destekleyen politikalar tarafindan düzenlenmediği için gelişememiştir. Devletin sanayileşememesinden kaynaklı olarak tarım dışı üretim sadece küçük imalathanelerle sınırlı kalmıştır. Yürürlükte olan serbest ticaret anlaşmaları ve kapitülasyonlar nedeniyle yerli üreticiler desteklenememekte, ülke içinde üretilen ürünler ithal edilen ürünlerle rekabet edememektedir (Pamuk, 2015, s. 141).

Osmanlı Devleti, sanayi üretimini geliştirememesine rağmen hizmet sektöründe önemli gelişmeler gerçekleştirebilmiştir. Fakat hizmet sektörü, her ne kadar yüksek miktarda sermaye sağlamış olsa da Müslüman olmayan tebaanın ve yabancıların kontrolünde olduğu için devlet ekonomisine önemli bir katkı yapmamıştır (Kepenek ve Yentürk, 2001, s. 9). Toplum, üretime katkısı olmayan dolayısıyla vergi ödemeyen yönetici sınıfıyla; üretici olan dolayısıyla vergi ödeyen halk olmak üzere iki kategoriye ayrılabilir. Halk ise kendi arasında ticaret ve sanayi ile uğraşan kentliler ve tarımla uğraşan köyüler olarak ikiye bölünmüştür (Kongar, 2013 s. 348). İşte, Kuyucaklı Yusuf romanı bu iktisadî koşullar içindeki bir toplumun tezahürü olarak kaleme alınmıştır.

Roman Kuyucak’ta eşkıyalarca işlenen bir cinayetle başlar. İktisadi açıdan eşkıyalık, devletin güçsüz olduğu anda ortaya çıkan ve gerektiğinde güç kullanmaktan kaçınmayan grupları işaret etmektedir. Eşk1yalık, romantik söylemlerin aksine genellikle zorbalık ve güç elde etmek isteği olarak ortaya çıkar. Kuyucaklı Yusuf romanında olduğu gibi yerel yöneticilerin, yöre halkından güçlü kişilerle birtakım karmaşı ilişkiler içinde olduğu yerler eşkıyalığa en elverişli bölgelerdir. Genellikle bu bölgeler sosyoekonomik olarak geri kalmış, merkezi otoriteden uzak ve feodal güçlerin halk1 yönlendirme güçlerinin yüksek olduğu yerlerdir. Bu tür bölgelerin yönetimi, gücünü toprak mülkiyetinden alan yörenin önde gelen ailelerinden biridir. Bu aileler arasındaki daimî rekabet eşkıyalara doğal bir talep yaratır ve yerel yönetimi elinde bulunduran feodal otoriteler, eşkıya ile savaşmak yerine bundan çıkar sağlama yolunu tercih edebilirler (Pıçak, Bulut ve Demir, 2020, s. 378) Dolayısıyla, herhangi bir üretim faaliyetine katılmayan eşkıyalar, üretilen mal ve hizmetlerin faydalarından nemalanmadan geri de kalmazlar hatta onlara yöneltilen talepten dolayı politik bir önem bile kazanabilirler

İlk andan itibaren roman, okuyunca insanın içini burkacak kadar yoğun yoksulluk betimlemelerini sunar. Bundan dolayı, bu çalışmada Hangenaars ve de Vos'un (1988, s. 211-221) yoksulluk tanımı kullanılacaktır. $\mathrm{Bu}$ tanımına göre yoksulluk yiyecek elde etmek, giyinmek ve barınmak gibi temel ihtiyaçların minimum seviyede bile karşılanamaması durumudur. Sabahattin Ali'nin Kuyucaklı Yusuf romanı da bu tanım doğrultusunda incelenecektir.

Romanın başından itibaren yoksulluk olay örgüsündeki diğer temaların önüne geçerek romanın ana teması haline gelir. Roman bu yoksulluğu şöyle vurucu bir tasvir ile okuyucularına yansıtır.

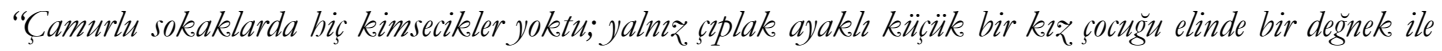
mütemadiyen bağıran ve çamurlu kanatlarmin telaşla çarparak koşan birkaç ką̧ kovalyor, onlar bir bahçe çitinin alt tarafindaki ufak delikten içeri sokmak istiyordu. Atlar görünce, kenardaki ekssi kokusu ta u₹aklara kadar yayllan bir gübre yuğmmn üzerine çıktı...” (Ali, 2010, s. 8).

Bu pasajdan anlaşılacağı üzere yoksulluk kavramını net bir biçimde vermek için yazar çamurlu sokaklarda çıplak ayakla dolaşan bir kız çocuğu tasvirine girişmiştir. Atlardan inen Kaymakam Salahattin Bey ve beraberindeki insanlar cinayet mahalline giderler. Salahattin Bey ve yanındakiler cinayet kurbanlarının yanında onları bekleyen oğulları Yusufla karşılaşırlar. Yusufun kimsesiz kaldığını öğrenen Kaymakam Salahattin Bey, erkek evladı olmamasını dönemin koşullarındaki ataerkil yaklaşımla eksiklik olarak da hissettiğinden Yusufu evladı olarak benimser ve yanına alır.

Bir süre sonra Kaymakam Salahattin Bey'in tayini Kuyucak'tan daha büyük olan Edremit'e çıar. Fakat Yusuf, köy yaşamını unutamayacak kadar büyüktür ve eğitim almayı gereksiz görür. Bunun nedeni romanın anlatıldığı çevrede eğitimle elde edilmiş yüksek bir toplumsal statünün olmayışıdır. Örneğin, en çok korkulan ve istediğine sahip olabilen ailenin Hilmi Bey'in ailesi olmasına rağmen romanda Hilmi Bey'in işinden ya da eğitiminden bahsedilmez. Kaymakam olarak oldukça iyi bir mevkide olan Salahattin Bey bile Hilmi Bey’in ailesinden çekinmektedir. Romanda, toplumsal statü paraya göre şekillenmektedir. Kötü huylan bilinmesine rağmen Hilmi Bey'in evi orada yaşayan insanlann içinde bulunmak istedikleri bir yerdir. Düzenlediği fasıllarda Salahattin Bey'in karısı, komşular orada yer almak için birbiriyle yarışmaktadır. 
Sabahattin Ali'nin tasvir ettiği yoksulluk, gelir dağılımındaki eşitsizlik vurgusunu da barındırır. Gelir dağıllımı, bir ekonomide belli bir dönemde yaratılan gelirin ne şekilde bölüşüldüğünü gösteren bir yaklaşımdır (Eğilmez, 2014, s.188). Ülke gelirinin tüm vatandaşlara eşit olarak dağıtılması beklenir ve vatandaşların bir bölümünün daha fazla ya da az pay alması gelir dağılımında eşitsizlik olarak nitelendirilir. Romanda, Yusufun işe aldığı anne ile kızın kaldığı ev, küçük bir kulübe olarak belirtilir. Evin zemini topraktandır ve duvarda açılmış küçük delik pencere görevi görmesi için cam konarak kireçle sıvanmıştır. Öte yandan romanın olay örgüsünde bahsedilen Kaymakam Salahattin Bey'in arkadaşı Hulusi Bey'in evi ise büyük ve güzeldir. Yaşam kalitesinin bir sembolü olarak fiskiyeli bir havuzunun olması da bu anlamda dikkat çekicidir.

Gelir dağılımındaki eşitsizliğin bir başka göstergesi ise işçilerin on sekiz saat karın tokluğuna çalısmasına rağmen zengin karakterlerden biri olan Hulusi Bey ve arkadaşlarının eğlence amacıyla kumar oynamasıdır. Kaymakam Salahattin Bey’in parasal durumu iyi olmasa da bir gün bu eğlenceye davet edilir ve üç yüz yirmi altın gibi oldukça ciddi bir miktarı kaybeder. Üç yüz yirmi altının o dönemin koşullarında bir senelik kaymakam maaşı ve bir zeytinliğin parasından daha fazla olduğu okuyucuya belirtilir. Bu olayın gerçekleştiği tarih tam olarak okuyucuya aktarılmamıştır fakat evlerde elektrikli aletlerin henüz kullanılmadığı, askerden geri dönen insanların olduğu bilgileri romanın Birinci Dünya Savaşı'nın hemen sonrası bir zamanda geçtiğini düşündürmektedir.

Gelir dağılımındaki eşitsizlik yalnızca tüketim açısından değil, hukuki açıdan da adaletsizliklere neden olmaktadır. Kıskançlık motivasyonuyla Şakir'in Ali'yi kalabalık bir ortamda öldürmesi bunu kanıtlar nitelikte bir olaydır. Şakir’in cinayeti işlerken kullandığı silah, Hacı Ethem'in verdiği rüşvet karşıllğında dönemin güvenliğini sağlamakla görevli olan kişilerden satın alınır. 1898 yılında dönemin Osmanlı padişahı II. Abdülhamid, Avrupa'da yaygın olarak kullanılmaya başlamış olan parmak izi uygulamasını Osmanlı'da da hayata geçirmek istemiş ve köyler de dâhil olmak üzere uygulamada bulunulmasını belirtmiştir (Sarıyıldız, 2008, s. 199; Demirci, 2013, s. 37). Cinayet silahının güvenliği sağlamakla görevli olan kişilerden rüşvet verilerek alınmasının bir nedeni, üzerinde Şakir'e ait olan parmak izlerinin bulunmasıdır. Bu delil ortadan kalktıktan hemen sonra cinayet tanıkları ifadelerini rüşvet aldıkları için değiştirir ya da tamamen geri çekerler. Bunun sonucunda Şakir serbest bırakılır. Romandaki örnekler göstermiştir ki gelir eşitsizliği gerek toplumda gerekse adalet sisteminde yüksek gelirli kişiler lehine bir yozlaşmaya neden olmuştur.

Yusuf ile Kaymakam Salahattin Bey'in kızı Muazzez arasında başlayan aşk, Salahattin Bey'in ölümü ile hemen hemen aynı zamana denk gelir. Toplumsal cinsiyet rolleri bağlamında erkeğe yüklenilen paranın idaresi, para kazanma yükümlülüğü, para yönetimi gibi görevler romanda kendine yer bulmuştur. Salahattin Bey'in ölümü üzerine evin geçimi yalnızca Yusufa kalmıştır. Romanda belirtildiği üzere, Yusufun o dönemde memur maaşı olarak aldığı ücret iki buçuk altındır ve bu meblağ o dönemin buzdolabı olan tel dolabı yalnızca bulgur pilavi ile doldurur. Buradan hareketle o dönemin memur maaşlarının yetersiz olduğu ve memurların temel gıda olarak en ucuz olan bulgur pilavı dışında diğer gıda ürünlerine ulaşamadıkları anlaşılmaktadır.

İktisat biliminin kurucusu sayılan Adam Smith, insanların rasyonel olmayan tutkularla hareket ettiğini söyler (Kesici, 2010, s. 94; Sarfati, 2008, s. 38). Sabahattin Ali gerek yoksulluk gerekse gelir dağılımındaki eşitsizliğin insani tutkuların bile önüne geçebileceğine Kuyucaklı Yusuf romanında dikkat çekmiştir. Kasabanın yozlaşma ve yoksullaşmasını anlatması bakımından Kuyucaklı Yusuf romanı önemlidir. Yukarıdaki analizlerden de görülebileceği gibi kasabadaki sorunların tamamı iktisat biliminin kendi içinde tartıştı̆̆ meselelere dayanmaktadır.

\section{Kürk Mantolu Madonna ve İktisat İlişkisi}

Kürk Mantolu Madonna romanı zaman ve mekân arka planı açısından Dünya Savaşları arasında Ankara ve Berlin'de geçer. İkinci Dünya Savaşı öncesindeki Türkiye'nin ekonomik şartları incelendiğinde Kurtuluş Savaşı bitmiş olmasına rağmen 1929 yllında meydana gelen büyük buhranın tüm ülkeler gibi Türkiye'yi de etkilediği açıktır. Türkiye tarımsal olarak uluslararası diş ticarette varlığını sürdürürken tarımsal mal fiyatlarında meydana gelen düşüş ile ihracat gelirleri azalmış ve hükümetin dış ticaret üzerinde daha korumacı bir politika izlemesine neden olmuştur (Pamuk, 2017, s. 173).

Birinci Dünya Savaşı sonrası Almanya, Versay Barış Antlaşması'na (1919) göre savaştan mağlup çıktıkları için İtilaf Devletleri’ne ödemeleri gereken savaş tazminatıyla karşı karşıya kalmışıtır. Ellerindeki kaynakların büyük bir bölümünü savaşı finanse etmek için kullanmışardır. Savaşın uzun sürmesi nedeniyle Almanya'nın dış dünya ile ekonomik ilişkisi hasar görmüş, ihracatı azalırken ithalatı artmıştır. Deflasyona 
karşı alınan önlemler, Alman ekonomisini daha da kötüleştirmiştir. Bu duruma ek olarak gelen Büyük Buhran ile tüm yabancı yatırımcısını kaybetmiş olan Almanya ekonomisi ağır bir süreçtedir (Robinson, 1944, s.636). Almanya'nın para politikası bakımından da başarısız olması enflasyonun hızla artmasına ve bu durum ekonomik koşulların istikrarsızlaşmasına neden olmuştur (Balderston, 1989, s. 242). Ankara'da yaşayan anlatıcının uzun zamandır bir iş arayışı vardır. Sabahattin Ali bu durumu “...buradan çıkınca nereye gideceğimi nerede iş arayacağımı bilememek... ve artık tamamıyla pençesine düşmüş olduğum çaresizlik..." (Ali, 2011, s. 17) cümleleriyle okura hissettirir. Türkiye'nin üst üste atlatmış olduğu savaşlar ve sonrasındaki 1929 Büyük Buhran düşünüldügünde dönemin Türkiye'sinde iş bulmakta zorluk çekilmesi kuvvetle muhtemeldir. Anlatıcı kendi aktarımıyla "çaresizlik" içinde iş arayışına devam ederken eski bir arkadaşıyla karşılaşır. Samimi sohbetleri, anlatıcının işsiz olduğunun öğrenilmesiyle yerini ikisi arasındaki bir uzaklaşmaya ve küçümsemeye bırakır. Anlatıcının ekonomik durumu nedeniyle iki arkadaş arasındaki ilişskinin dinamikleri sınıf ayrımının belirgin olarak hissedilmesine neden olacak kadar değişmiştir. Romanın ilerleyen sayfalarında anlatıcı, arkadaşı tarafından işe alınır. Yeni işinde kırk ila elli lira arasında ücret alacağı belirtilir. Romanda olayların geçtiği tam tarihler bilinmemektedir. Bu sebeple okur, ücret aralığının alım gücü açısından yorumlamasını yapamaz ancak anlatıcının yaz döneminde kazancının "beş ila on kuruş" olması okura bir başka açıdan karşılaştırma firsatı sunar. Arkadaşı tarafından işe alınmak anlatıcının üzerinde psikolojik bir rahatsızlık hissi vermiş olsa da uzun süredir işsiz olması nedeniyle iş teklifini kabul eder. Romanın bel kemiğini oluşturan karakter, Raif Efendi, okurla anlatıcının yeni iş yerinde çalışan bir tercüman olarak tanışır.

Romanda anlatıc1, Raif Efendi'yi sessiz ve içine kapanık biri olarak betimlemektedir. Bu nedenle çalıştı̆̆ dairedeki iş arkadaşlarıyla birlikte yemek yemez ve eğlenmez. Almanca çevirilerle ilgilenen Raif Efendi'nin bu içine kapanık duruşu çevrede Almancayı pek bilmediği dedikodusunun yayılmasına neden olmaktadır. Öte yandan hikâyenin devamında Raif Efendi’nin Almanya'da bir süre kaldığını ve oldukça iyi derecede Almanca bildiğini öğreniriz. Raif Efendi’nin masşı, diğer çalışanlarla kıyaslandığında hemen hemen hiç arttırılmaz ve Raif Efendi de bu duruma bir itirazda bulunmaz. Bu durumun nedeninin romanın başlangıcında anlatııının vurguladığı İkinci Dünya Savaşı öncesi Ankara'daki işsizlik sorunu ve Raif Efendi’nin hayattan bir beklentisinin kalmamış olması olduğu söylenebilir. Öyleyse Raif Efendi, emeği karşılığında aldığ1 ücrete itirazda bulunursa onun çalışı̆̆ı ücret seviyesinde çalışmak isteyecek birçok çalışan bulunabilir. İyi derecede Almanca biliyor olması onu diğer çalışan adaylarından ayırıyor olsa da yine de işini tehlikeye atabilecek bir durumda değildir. Bu durumda işsizlik oranı, Raif Efendi’nin çalışma ücretini hesaplarken göz önünde bulundurulması gereken bir değişkendir. Aslında bu anlatılanlar iktisat biliminde ücret teorisi olarak karşımıza çıkmaktadır ve romandaki uygun değişkenler kullanılarak kolaylıkla açıklanabilmektedir.

İşçinin emeği karşıllğında aldığı paraya ücret denir. Ücret belirlenirken pek çok değişken ücretin belirlenmesinde önemli rol oynamaktadır. Mal ve hizmet fiyatlarında meydana gelen düzenli artışlar (enflasyon), elde edilen ücretin değerinde değişikliklere yol açar, diğer bir deyişle ücretin karşıladığı mal ve hizmetlerin sayısı azalır. Bu nedenle iktisat literatürü ücret hesaplamalarında enflasyonu da dahil eder. Enflasyonun dahil edildiği ücrete reel ücret denir. Reel ücret, nominal ücretin beklenen fiyat düzeyine bölünmesiyle elde edilmektedir. Reel ücretin belirlenmesi ise iki temel faktörden etkilenmektedir; işsizlik oranı ve çalışanı motive eden ücret dışı değişkenler.

Çalışmak isteyen ve aktif olarak iş arayan insanların sayısının yüksek olduğu durumlarda çalışma ücretlerinde azalma meydana gelmektedir. Bunun nedeni çalışmak isteyen fakat iş bulamayan insan sayısının fazla olmasıdır. Kısaca iş gücü talebi az fakat arzı fazladır. Öyleyse işsizlik oranının yüksek olması reel ücretin belirlenmesinde negatif bir etkiye sahiptir. Reel ücretin belirlenmesinde bir başka önemli değişken ise ücret yerine geçebilecek, çalışanları motive edici uygulamalardır. Hastayken izin alabilme kolaylı̆̆, tatile göndermek, iyi davranmak, özel günlerde hediye dağıtmak vb. durumlar bu motive edici uygulamalara örnek verilebilir. Çalışanlar doğrudan ücretlerine zam almasalar da çalıştıkları yerde mutlu oldukları için doğrudan bir zam talebinde bulunmayabilirler. Bu durumda motive edici uygulamalar arttıkça, reel ücrete pozitif etkide bulunduğu söylenebilir. Raif Efendi’nin hastayken izin alamaması, patronunun ve diğer iş arkadaşlarının gösterdiği kötü muameleler düşünüldüğünde romanda ücret yerine geçebilecek motive edici uygulamaların reel ücrete negatif etki yaptığ1 kuvvetle muhtemeldir. Raif Efendi'nin negatif etkilere ve arttırlmayan ücretine itirazda bulunmama sebebi ise işsizlik oranın çok yüksek olması olarak düşünülebilir çünkü Raif Efendi’nin geçindirmesi gereken oldukça geniş bir ailesi vardır. 
Romanın içindeki bir diğer iktisadi bağıntı Raif Efendi’nin defteriyle Birinci Dünya Savaşı sonrasındaki dönemin anlatımına geçilmesiyle ortaya çıkmışıtı. Birinci Dünya Savaşı, Osmanlı Devleti'nin de içinde bulunduğu İttifak Devletleri açısından yenilgiyle sonlandığında Raif ve ailesi köyde yaşamaktadır. Osmanlı Devleti'nde yer yer başlayan işgallerle Raif, babası tarafından tahsilini tamamlaması için İstanbul'a gönderilir. Birinci Dünya Savaşı'ndan bir diğer yenik çıkan devlet ise Almanya'dır. Savaş sonrasında Alman hükümetinin harcamalarındaki artış, vergileri arttırarak, piyasaya devlet tahvilleri sürerek ve para basarak kapatılmaya çalı̧ılmıştır (Mishkin, 2004, s. 633). Bu dönemde uluslararası piyasada geçerli olan para sistemi bir tür sabit döviz kuru olan Altın Standardı Sistemi'dir. Altın Standardı Sistemi’ne göre ülkelerin diğer ülkelere göre parasının değeri ülkenin sahip olduğu altın rezervine göre belirlenmektedir. Birinci Dünya Savaşı sırasında devletlerin harcamaları arttığından altın rezervleri dikkate alınmadan para basılmaya başlanmıştı. Almanya da bu ülkelerden biriydi (Tooze ve Fertik, 2014, s. 225). Savaş sırasında savaş masraflarını karşılamak zorunda olduğundan daha sonrasında da galip ülkelere savaş tazminatlarını ödediğinden, Almanya hükümetinin harcamaları artmış ve bunu karşılamak için rezervlerden bağımsız olarak para basmaya başlanmışıtı (Roesler, 1967 Akt: Balderson, 1989, s. 226). Dolaşımda olan Alman parası (Mark) miktarı arttıkça, Mark'ın değeri düşmüştür. Paranın değerinin düşmesi, paranın en önemli işlevlerinden biri olan satın alma gücünü azaltmıştır. Diğer bir deyişle mal ve hizmetlerin fiyatlarında sürekli bir artış meydana gelmiştir. Almanya'nın Birinci Dünya Savaşı'nda yaşadığı enflasyon oldukça yüksek olduğunda hiperenflasyon olarak isimlendirilmiştir. Fiyatlarda meydana gelen sürekli artış bir kısır döngü oluşturarak Mark'ın değerini yeniden düşürmüştür. Bu sırada savaş nedeniyle üretimde ve iş gücünde azalma meydana gelmiştir ve bu durum da fiyatlarda artış meydana getirmiştir (Çağlar ve Dışkaya, 2018, s. 1-24). Mark'ın değeri gittikçe azalmıştır.

Gerçekleşen bu durum iktisadi detaylarla şöyle açıklanabilir: Para basılması sonucunda piyasada bulunan para miktarı "para arzı" artar. Para arzı; toplam çıktı miktarının, nominal faizin likidite fonksiyonuyla çarpımına eşittir. Nominal likidite fonksiyonu, para arzıyla ters ilişkilidir. Bahsettiğimiz gibi para basılarak para miktarında meydana gelen artış, para piyasası aracıllŏıyla toplam çıktı miktarının/ üretimin artmasına neden olur. Bu artışın sonuçlarından biri olarak nominal faizde düşüş meydana gelir. Para piyasasında meydana gelen artıs sonrasında para, mal ve hizmet piyasalarının dengesiyle oluşan toplam talep eğrisinde de artşs meydana gelir. Toplam talebin artmasıyla bozulan toplam arz ve toplam talep dengesi fiyatların artış yoluyla tekrar dengeye gelecektir.

Nominal faiz, reel faiz oranının beklenen enflasyonla toplanmasıyla hesaplanmaktadır. Enflasyonun sabit varsayılması durumunda, nominal faizlerde gerçekleşen düşüss, reel faizlerde aşağı doğru bir harekete sebep olacaktır. Bir diğer deyişle reel faiz oranları ile para arzı arasında negatif yönlü bir ilişki mevcuttur. $\mathrm{Bu}$ ilişkide meydana gelen değişimler belirtilen ülkenin döviz kurunda da değişime neden olmaktadır. Dolayısıyla Almanya'nın para basması, ilgili değişkenlerin birbirini etkilemesiyle Mark'ın yabancı paralar karşısında değer kaybetmesine neden olmuştur. Hem Mark'ın değer kaybetmesinden yararlanmak hem de yeni üretim tekniklerini öğrenmek ve bunları kendi ülkesinden uygulamak isteyen Raif in babası oğlunu Almanya'ya sabun imal etmeyi öğrenmesi için yollamıştır.

Almanya'nın para basması, para arzını arttırmıştır. Artan para arzı ile birlikte Mark'ın getiri oranı (faizi) düşmüştür. Faizlerin gerilemesi, Türk Lirası'nın Mark karşısındaki beklenen getirisini göreceli olarak arttırmakla birlikte Türk Lirası'nın Alman Mark'ı karşısında değerini arttırmışır. Romanın baş karakteri Raif Almanya'ya gittiğinde orada tanıştığı Maria Puder, nam-1 diğer Kürk Mantolu Madonna'ya âş̧ı olur. Maria ile Raif arasında geçen bir sohbette hiperenflasyon döneminin Alman vatandaşların parasını nasıl erittiğini ve yoksullaştığını okuyucu Maria'dan öğrenir. Romanın devamında anlatılan aşk hikayesi Raif in babasının ölümü ve ailesinin Raif'e para gönderemeyecek olmasıyla kesintiye uğrar. Raif, Türkiye'deki işlerini düzenlemek amacıyla Almanya'dan ayrılır ve iki aşık bir daha birbirlerine ulaşamazlar. Raif Efendi evlenir ve geniş bir aile ile yaşam sürmeye başlar. Ağır bir hastalığa yakalanmadan hemen önce Maria'dan çocuk sahibi olduğunu ve Maria’nın öldüğünü ögrenir. Umutsuzluk ve üzüntü ile karda yapılan uzun bir yürüyüşten sonra rahatsızlanır ve bu rahatsızlı onu ölüme kadar götürür.

Kürk Mantolu Madonna romanı, okuyucuya yalnızca bir aşk hikayesi vermekle kalmamıs, onu satır aralarında işlediği sosyal ve ekonomik notlarla dönem hakkında bilgilendirmiştir. Romanda, Cumhuriyet döneminin başında bile insanların ekonomik durumlarının toplumsal statülerini belirlediği ve insanlar arasında yarattığı ayrıştıııcı etki, anlatıcı ve arkadaşı arasında net bir şekilde gözlemlenmektedir. Raif Efendi’nin emeği karşısında aldığı ücrete itiraz edememesi ise işsizliğin, ücretin belirlenmesindeki önemli etkisini gözler önüne sermiştir. Birinci Dünya Savaşı'nda ortaya çıkan savaş tazminatlarını ödemeye çalısan 
Almanya'nın kontrolsüz para basması ise ülkeyi önce enflasyona, sonrasında ise hiperenflasyona sürükleyerek paranın değerini azaltarak halkın alım gücünü düşürmüştür.

Kürk Mantolu Madonna, Birinci Dünya Savaşı sonrasındaki Almanya ekonomisi ve İkinci Dünya Savaşı öncesindeki Türkiye ekonomisini roman akışına dahil ettiği için iktisadi açıdan önemli romanlardan biridir.

\section{Tartışma, Sonuç ve Öneriler}

Son yıllarda iktisat biliminin pozitif bilimlere yaklaşmaya başladığı gözlemlenmektedir. İktisat bilimine konu olan olayları açılamak için kullanıla modellerde insana ait etkilerin dışlandığı veya kullanılan varsayımlarla bu etkilerin sınırlandırıldığı gözlemlenmektedir. Fakat iktisadi olayların sadece matematiksel işlemlerle açıklanamayacak kadar toplumsal veri taşıdığı da ortadadır. Dolayısıyla edebiyat, toplumun içinde bulunduğu durumu yansıtması bakımından oldukça faydalı bir araçtır. Bazı edebiyat eserleri bunu bütün ön yargılardan arındırarak doğrudan okuyucuya aktarırken, bazı eserler ise olası çevresel etkenleri olabildiğince azaltarak duygusal yoğunlukla okuyucuya aktarmaya çalısır. İktisadi olayların daha net olarak anlaşılması için toplumun içinde bulunduğu durumu analiz eden edebi eserlerden faydalanılabileceği düşünülmektedir.

Araştırmanın inceleme nesnesi olan Kuyucaklı Yusuf ve Kürk Mantolu Madonna romanları her ne kadar aşk romanı olarak algılansalar da Sabahattin Ali’nin ustalıkla kullandığı gerçekçilik yaklaşımıyla toplumsal, ekonomik ve sosyal durumları olduğu gibi yansıtarak okuyucuya detaylı çıkarımlar yapması için firsat sunmuştur.

Kuyucaklı Yusuf romanında yoksulluk ve gelir eşitsizliği gibi iktisadi konular ile yaşam kalitesi ve adaletsizlik arasındaki ilişkiler ortaya konulmuştur. İktisadi olayların, toplum yapısı üzerindeki önemini göstermesi açısında güzel bir eser olduğu söylenebilir.

Öte yandan Kürk Mantolu Madonna, tek roman içinde iki farklı ülkenin iki farklı zaman aralığına dikkat çekerek farklı toplumların iktisadi durumları hakkında yorum yapmamızı yardımcı olmaktadır. Romanda, İkinci Dünya Savaşı öncesinde işsizliğin yarattığı toplumsal statü farklılı̆̆ı, işsizlik oranlarının belirlediği emeğin karşıllğı olan ücretin yetersiz olmasına rağmen ücrete itiraz edilememesiyle Türkiye'nin yaşadığ1 ekonomik sıkıntılara işaret edilmektedir. Ayrıca, Birinci Dünya Savaşı sonrasında hiperenflasyon sürecine girmiş olan Alman ekonomisi ve halkın alım gücündeki olumsuzluklar en net haliyle ortaya konulmaktadır.

İncelenen eserlerde, Sabahattin Ali'nin diğer eserlerinde de olduğu gibi, sınıf farkliliklarının altı çizilmektedir. Zengin-fakir, işveren-işçi gibi sınıfsal özellikler içeren karakterler eserlerde oldukça gerçekçi bir şekilde ortaya koyulmuştur. Bu tür sınıfsal ayrımlara gidilmesinin Sabahattin Ali’nin ideolojik bakış açısından kaynaklandığı açıktır fakat dönemin Türkiye'sini de temsil ettiği inkâr edilemez. Eserlerde sistem siyasal ve iktisadi açıdan açıkça eleştirilmekte ve sistemin daima güçlüden yana olduğu vurgulanmaktadır. Gücün tek kaynağı paradır, paraya sahip olan güce de sahiptir. Bu bağlamda sistem güçlüye hizmet etmektedir. Fakir olan işçi ve köylü sınıfı kaçınılmaz olarak bu güç duvarına hayatlarında en az bir kez çarpmaktadırlar. Bu tür bir çarpışmada kimin hasar göreceği sorusunun cevabı ise toplumun bütün bireyleri tarafindan bilinmektedir.

Sabahattin Ali'nin iki romanın incelenmesiyle iktisadi kavramların edebiyat eserlerinin temelinde görünenden daha derin bir yerde olduğu ortaya konulmaya çalışıııştır. Bu bakımdan incelenen eserler işsizlik, gelir eşitsizliği, yoksulluk, sınıfsal çatışma, hiperneflasyon, döviz kuru ve sosyal adalet gibi iktisat biliminde de yer alan kavramların açıklanması açısından oldukça faydalı olduğu görülmektedir.

Birçok çalışmada olduğu gibi bu çalışmada da kısıtlar bulunmaktadır. Örneğin, Raif Efendi’nin ücret artırma talebinde bulunmaması, Yusufun tarım ile ilgilenmiyor olması gibi aslında iyi bir romanda tutarlı ve sağlam bir karakter oluşturmak için yazarın bilinçli olarak karakterlere yüklediği özellikler olabilir. Bu tür davranışlar zaten romandaki o karakterden beklenen davranışlardır. Salt karakter açısından düşünmenin ötesinde, bir romanın ana yapısı içinde ince ince tüm psikolojik ve eylemsel tepkiler işlenir. Bu bağlamda ilgili karakterlerin davranışlanını sadece iktisat teorisi bağlamında açıklamanın tek başına yetersiz olacağı ortadadır. Bu noktada ilgili karakterler hakkında yapılan iktisadi açılamaların, karakterlerin böyle davranmasına yol açan faktörlerden sadece biri olabileceği göz ardı edilmeden yorumlanması daha yerinde olacaktır. Böylece aşırıya kaçan karakter yorumlardan da kaçınılabilecektir. 
Temel konusu insan davranışlarının modellemek olarak belirleyen iktisat biliminin farklı yöntemlerle öğretilmesi bağlamında edebi eserlerin kullanılmasının ve bu konunun başka çalısmalara da konu olması olasıllğı yüksektir. Romanlar iktisadi açıdan genel olarak değerlendirilebileceği gibi romanlardaki karakterlerin temsil ettiği sınıflar-iktisadi gruplar da analiz edilebilir. Bu grupların iktisadi yapı üzerindeki etkileri veya iktisadi yapının bu gruplara olan etkileri de farklı bir araştırma konusu olabilir.

\section{Etik Beyan}

"Sabahattin Ali Romanlarndaki İktisat Teorisi İ̃leri” başlıklı çalışmanın yazım sürecinde bilimsel kurallara, etik ve alıntı kurallarına uyulmuş; toplanan veriler üzerinde herhangi bir tahrifat yapılmamış ve bu çalşsma herhangi başka bir akademik yayın ortamına değerlendirme için gönderilmemiştir. Bu araştırmada doküman incelemesi yapıldığından etik kurul kararı zorunluluğu bulunmamaktadır.

\section{Kaynakça}

Akyol, E. (2013). Sultan II. Abdülhamid döneminde sosyal politika uygulamaları. Sosyal Politika Calısmalar, 31, 33-47. doi: $10.21560 /$ spçd. 18817

Ali, S. (2010). Kuyucakll Yusuf ( 42. Bask1). İstanbul: Yap1 Kredi Yayınlar1.

Ali, S. (2011). Kürk Mantolu Madonna ( 47. Baskı). İstanbul: Yap1 Kredi Yayınları.

Balderston, T. (1989). War, finance and inflation in britain and germany 1914-1918. The Economic History Review, 42(2), 222-244. doi: $10.2307 / 2596203$

Çağlar, Ü. ve Dışkaya, S. K. (2018). Küreselleşme, uluslararası para sistemi ve kriz. İktisat Politikası Arasstrmaları Dergisi, 5(2), 1-24. Erişim Adresi: https://dergipark.org.tr/en/pub/iuipad/issue/38690/449629

Eğilmez, M. (2014). Örneklerle Kolay Ekonomi (12. Baski). İstanbul: Remzi Kitabevi.

Hagenaars, A. ve de Vos, K. (1988). The definition and measurement of poverty. The Journal of Human Resources, 23(2), 211-221. doi: $10.2307 / 145776$

Kazgan, G. (1991). İktisadi dïssinnce ve politik iktisadn evrimi (21. Baskı). İstanbul: Remzi Kitabevi.

Kepenek, Y. ve Yentürk, N. (2001). Türkize ekonomisi (12. Baskı). İstanbul: Remzi Kitapevi.

Kesici, H. (2010). Adam Smith ve ahlak teorisi. Journal of Social Policy Conferences, 1(58), 89-97. Erişim Adresi: https://dergipark.org.tr/en/pub/iusskd/issue/887/9867

Kishtainy, N. (2017). Ekonominin kessa taribi (4. Baskı) (Çev: A. Yllmaz). İstanbul: Alfa Basım.

Kongar, E. (2013). 21. Yüryylda Türkive (21. Baski). İstanbul: Remzi Kitabevi.

Korkmaz, R. (1991). Sababattin Ali - Insan ve Eser (Doktora Tezi). Fırat Üniversitesi Sosyal Bilimler Enstitüsü, Elazı̆̆. Erişim Adresi: https://openaccess.firat.edu.tr/xmlui/handle/11508/14545

Krugman, P., Obstfeld, M. ve Meliz, M. (2018). Money, interest rates, and exchange rates, international economics. International Economics içinde (414-444). London: Pearson Education Limited.

Mishkin, F. (2004). Money and Inflation. The economics of money banking and financial markets içinde (632-658). Boston: Pearson, Addison Wesley.

Moran, B. (2018). Kısım I, Edebiyat kuramlar ve eleştiri (28. Baskı). içinde (ss.17-84). İstanbul: İletişim.

Nesin, A. (1976, 14 Şubat). Sabahattin Ali'yi unutturmamak. Cumburiyet Gazetesi, s. 7.

Özdemir, N. (2011). Edebiyat ve ekonomi kültürel ekonomik bir alan olarak edebiyat. Millı Folklor, 91, 101-114. Erişim Adresi: https://www.millifolklor.com/PdfViewer.aspx?Sayi=91\&Sayfa=98

Pamuk, Ș. (2015). Türkiye'nin 200 yıllhk iktisadi taribi (5. Baskı). İstanbul: İş Bankası Kültür Yayınları.

Pamuk, Ş. (2017). Osmanldan Cumburiyete küreselleşme, iktisat politikalar ve büyüme (4. Baskı). İstanbul: İş Bankası Kültür Yayınlar1.

Pıçak, M., Bulut, M. ve Demir, Ş. (2020). Eşkıyaların merkezi devlet ve feodal otoritelerle ilişkileri. Journal of Social Science, 4(7), 377-393. doi: 10.30520/tjsosci.684434

Robinson, N. (1944). German foreign trade and industry after the first world war. The Quarterly Journal of Economic, 58(4), 615-636. doi: 10.2307/1884747

Sarfati, M. (2008). Görünmeyen el metaforu. Ekonomik Yaklașm, 19(66), 29-71. doi: 10.5455/ey.10659

Sarıyıldız, G. (2008). Osmanlı bürokrasisinde fotoğraflı belge kullanımı ve parmak izi uygulaması. İstanbul Üniversitesi Edebiyat Fakültesi Tarib Dergisi, 1(47), 183-208. Erişim Adresi: https://dergipark.org.tr/en/pub/iutarih/issue/9620/120175

Şenderin, Z. (1996). Sabahattin Ali'nin eserlerinde toplumsal gerçekçilik (Yüksek Lisans Tezi). Kurıkkale Üniversitesi, Sosyal Bilimler Enstitüsü. Kırıkkale.

Tooze, A. ve Fertik, T. (2014). The world economy and the great war. Geschichte und Gesellschaft. 40(2), 214-238. Erişim Adresi: https://www.jstor.org/stable/24368710

Treaty of Versailles (1919). Article 132. Erişim Adresi: https://www.loc.gov/law/help/us-treaties/bevans/must000002-0043.pdf

Wilson, R.N. (1952). Literature, society, and personality. The Journal of Aestheticsand Art Criticism, 10(4), 297-309.

Watts, M. ve Smith. R.F. (1989). Economics in literature and drama. The Joumal of Economic Education, 20(3), 291-307. doi: 10.1080/00220485.1989.10844633 
Watts, M. (2002). How economists use literature and drama. The Journal of Economic Education, 33(4), 377- 386. Erişim Adresi: https://www.jstor.org/stable/1183139

Wellek, R. ve Warren, A. (2011). Edebiyat teorisi. Dergâh Yayınları.

\section{EXTENDED ABSTRACT}

Literature and economics have an implicit but dynamic relationship as they analyze the society and the people with different methods. The main reason for the dynamic relationship is that societies have different needs and habits based on the culture and living standards. As needs and habits change, society is expected to show differences in economic trends as well. In economic literature, many economists have mentioned that economics and art/literary feed each other socially.

Therefore, when a certain period in a society is analyzed economically, it is very useful to consider the historical, social, and cultural backgrounds of that period. It can be said that some of these studies conducting on the literary will be a good occasion for the literature and economics that share the same foundation to show that they can feed each other from different perspectives. In fact, since literary often is influenced by the history, culture, and traditions, they emerge as a useful tool for understanding the background of the society. The useful tool provides the opportunity to observe the way individuals are affected by an economic structure of a certain period by removing unseen historical periods from the superficiality in the history books. As a result of observations about individuals, more significant results can be achieved by comparing the results in micro and macroeconomic theories with individual observations.

The main purpose of this article is to draw attention to the "stronger than predicted" relationship between economics and literature. And to analyze the relationship between economics and literature in the international economics literature in terms of Turkish literary and the economic periods they belong to. In this study, Sabahattin Ali's Kuyucaklı Yusuf and Kürk Mantolu Madonna novels were deemed suitable for evaluation, as they had a clear traces of the social and economic structure of the period in which they were written. In this study, starting from the relationship between economics and literature, the event flows of the novels of Kuyucaklı Yusuf and Kurk Mantolu Madonna, respectively, have been defined and the economic traces of the two novels have been evaluated. The novel of Kuyucaklı Yusuf is based on the theme of poverty and this theme is also supported by income inequality in village/town life in the fall of the Ottoman State in the book. In light of these themes, events such as determining the social status depend on income, not attach importance to education, working conditions of agricultural workers, and obstruction of justice occur during the storyline of the novel. Therefore, it can be said that when the economic situation of the Ottoman State in the history of economics is examined, it is observed that events of the period and the events in the novel are related. On the other hand, the novel of Kurk Mantolu Madonna has two different timelines as the Turkish economy before the Second World War and the German economy after the First World War during the storyline. The no-name narrator and mister Raif face the problem of uncertainty and unemployment problems at the Turkish economy before the Second World War. In the German economy after the First World War, Maria Puder gives voice to the economic problems of Germany and the effects of the economy (inflation, unemployment, etc.) on German society. The same as in the Kuyucaklı Yusuf novel, Kurk Mantolu Madonna's novel has a connection between the historical and economic situation of the historical periods and the storyline of the characters.

According to the analysis, it is concluded that many economic concepts are based on the situations and events that form the subject of literary works. This result also gives a different perspective to the science of economics, which has begun to lose its social contact points and becomes mechanized. Namely, the possibility emerges again that literary can be used especially in economics education and the theory of economics can be explained through these novels. In this way, economics students can realize that the economic theories they learn are intertwined with wide interdisciplinary topics and they can discover the importance of economics in daily life more easily. With the use of literary in economics education, it is also aimed that the economics students can ascertain the cause-effect relationship, the butterfly effect that these relationships might cause, and the impact area of human behavior on the economic base.

In addition, the relationship between economics and literature can be used as a data set in behavioral economics studies, as well as for policymakers to draw lessons from the past and prepare appropriate projections for the future. 